\title{
A CASE OF CEREBRAL EXHAUSTION MISTAKEN FOR ONE OF PARESIS ${ }^{1}$
}

\author{
By Theodoré Diller, M.D.
}

PITTSBURGH.

In a recent report, Dr. J. Ramsey Hunt ${ }^{2}$ calls attention to cases in the army which he had examined exhibiting symptoms resembling paresis and which he considered to be cases of exhaustion. $\mathrm{He}$ stated he had never seen a similar case in his private or hospital practice.

It has been my own experience on a few occasions-perhaps not more than two or three times - to have seen cases of profound cerebral exhaustion which, for a time, I considered to be cases of organic disease; and in one instance $I$, for a time, believed a profound case of psychesthenia to be a case of brain tumor.

I have not seen any such case in a number of years; and so deem worthy of record as a further contribution on this subject (with Hunt's report in mind) a case of this sort at present under observation.

CASE I. A man aged thirty; hotel business with his father; married five years; two children. He smokes a great deal; drinks only a little. He was brought to me by his mother who notes that he looks tired all the time. She states that for a number of weeks he has been forgetful. She says she must tell him things over and over again. He often repeats himself within five or ten minutes. He is nervous also as shown in his handwriting. These symptoms have been developing for several weeks past.

At the age of four he suffered a severe attack of scarlet fever which left him with a discharge at one ear, which, despite treatment from a number of physicians, continues up to the present time.

Upon examination the patient looked tired, weary, stupid and heavy. His face lacked expression and was suggestive of that seen in myesthenia; it exhibited marked facial tremor; articulation was slurring in ordinary speech and this became marked when he attempted to repeat the ordinary test phrases. He writes laboriously and with great effort and handwriting exhibits a marked tremor.

1 Case presented in brief in discussions in Section of Nervous and Mental Diseases at meeting in Chicago, June I2, I9I8.

2 Journal of Nervous and Mental Disease, March, rgi8. 
In a mental way the patient is dull, languid, stupid, apparently disinclined to make any effort, even in conversation. There was no euphoria.

$$
\text { woll }
$$

Thasis a sficumen of mey hand innting pearch. $2 v, 19,8$

ivaled cotehn

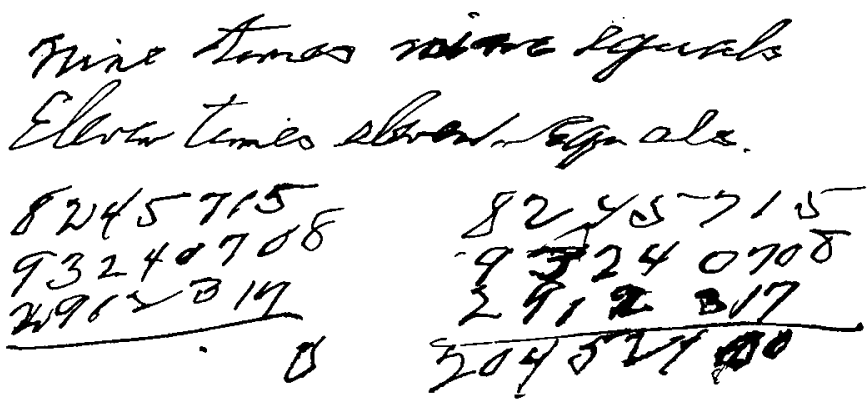

I sent him to St. Francis quite confident that in spite of the fact that the knee jerks and pupils reacted normally that we should find

$$
\text { et oframas Hosfital. }
$$

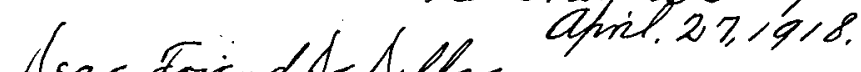

Wear Triend Dr weller.

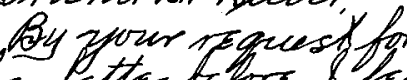

anither lefter fefore o leaw the hushas pol

will to think es smongh to tater utya fow ifs zow town it is pretty hard to write minch of and thing of initers pis - frdo not get a change: to see much mor s than fun or als across the way and the nurses when they come to mey rom. zuell it re dmust say that I am cortaply glad Incant har whow hdid for it surb has

the laboratory evidence indicative of syphilis. Much to my surprise the examination of the blood and spinal fluid were entirely negative. 
Now I began to make a reëxamination of the man. Gradually it dawned on me that I was dealing with a case of cerebral exhaustion, rather than paresis. It was then that I read Hunt's report. The case then appeared to me quite clear.

To make a long story short, the patient has steadily improved since he entered the hospital about five weeks ago. The defect of articulation, so prominent at first, is now scarcely noticeable. The improvement in his handwriting is perhaps even more marked. At first it showed a very marked tremor and many words were misspelled. Recently a four-page letter which he produced for me exhibited handwriting which is about normal. Perhaps the most striking change is in his face which now lights up with animation and no longer exhibits the ironed-out expression which it presented when he first came to me.

Only recently I learned from the patient a further important item of history which was not elicited when I first saw him which is, namely, that he had been working twelve to fourteen hours a day steadily for many months before I saw him as a clerk in the hotel. He said that he was "dead tired" all the time.

This case carries with it its own comment, I think. I need hardly say anything further. 